\title{
METHODOLOGICAL PROBLEMS OF LAND USE ENVIRONMENTAL IMPACT ASSESSMENT AS A PLANNED ECONOMIC ACTIVITY
}

\author{
A.M. Tretyak, Doctor of Economics, Professor \\ E-mail: tretyak2@ukr.net \\ I.A. Klimova, Postgraduate student
}

State Ecological Academy of Postgraduate Education and Management of the

Ministry of Energy and the Environment

E-mail: iklimova217@gmail.com

\begin{abstract}
Assessment of the environmental impact of land use as a planned economic activity related to a number of issues, in particular theoretical and methodological character. One of the main problems in the development of such a theory is to built its basis, the starting point for the development of which is to determine the methodological procedure.

Despite the large amount of literature devoted to the study of various aspects of environmental impact assessment, it is necessary to state that no sustainable, complete definition of this concept has been formed in the environmental literature.

The purpose of the article is to review and compile directions and approaches formed by certain criteria in the doctrine of environmental legislation to define the concept of environmental impact assessment of land use as a planned economic activity, to cover their heterogeneous and general nature for developing a holistic view of ways of understanding this concept, as well as an account of one's own vision of the optimal methodological basis for defining the concept of environmental impact assessment of land use.

From the example of foreign experience it is established that in the modern period the following procedures are widely recognized: previous environmental impact assessment - screening; definition of environmental assessment tasks scoping; generalization, comparison and choice of alternatives.
\end{abstract}


From the authors' point of view, it is proposed to supplement the environmental impact assessment with the following steps as well: assessment of environmental parameters; mitigation; decision making.

Based on the analysis of the considered methodologies for environmental situation assessment, we propose a methodology for geoinformation land-ecologicaltechno-geochemical modeling of environmental situations, based on the use of GIS technologies for graphical overlay of evaluation maps [1].

This methodology is the optimal basis for determining the environmental impact assessment of land use as a planned economic activity, both in the early stages of environmental impact assessment and when comparing alternatives.

Keywords: concept of environmental impact assessment of land use as a planned economic activity; evaluation procedures; planned business activities, "screening"; "scoping"; "generalization"; "Methodology of geoinformation landecological-techno-geochemical modeling"; GIS technologies.

\section{INTRODUCTION}

One of the priorities of the national security of Ukraine is the introduction of environmentally and technologically safe land use conditions of various types for the life of citizens and society, environmental conservation and the rational use of land and other natural resources. The environmental safety of the state is based on the institutional environment in Ukraine and depends on many factors, including the impacts of land use on the livelihoods of citizens and the environment.

In order to prevent environmental degradation and reach a normatively safe level of environmental components, it is necessary to conduct a consistent effective environmental policy aimed at protecting the life and health of people, land and other natural resources, by enacting environmental, land and other laws and regulatory legal and methodological documents. An integral part of such a policy in the leading countries of the world is the systematic procedure of environmental impact assessment (EIA), which is used as a tool for preventive environmental regulation of economic activity. An analysis of the accumulated international experience allows us 
to establish a number of general laws that make this tool effective and little dependent on the conditions of a particular country.

The main legislative act in the field of ATS in Ukraine is the Law of Ukraine "On Environmental Impact Assessment" (2018), and the general requirements for the compilation of sections of the Report on Environmental Impact Assessment defined in Article 6 of this law [2].

According to Article 1 of the Law of Ukraine "On Environmental Impact Assessment" - environmental impact is any environmental impact of the planned activity, including consequences for the safety of human life and their health, flora, fauna, biodiversity, soil, air, water, climate, landscape, natural territories and objects, historical monuments and other material objects or for the combination of these factors, as well as the consequences for cultural heritage or socio-economic Words that are the result of changes in these factors [2]. Given that most types of economic activity are carried out on a land plot and this process is called land use, it is legitimate to consider the consequences of land use on the environment, both within the land plot and beyond. Activities such as agricultural, forestry, recreational and others are directly carried out using land and other natural resources, while others use the land as a territory for the placement of economic activities. In both cases, anthropogenic environmental impact is carried out, only methodologically the environmental impact assessment will be different.

The practice of conducting ATS in Ukraine shows that the assessment procedure has not yet become the process that accompanies all stages of an investment project, from the moment of the project idea, as is customary in world practice, to the moment of implementation of the activity and after the project is implemented [1].

According to the Law of Ukraine "On Environmental Impact Assessment", environmental impact assessment is a procedure that provides for:

1) preparation by the enterprise of a report on environmental impact assessment in accordance with Articles 5, 6 and 14 of the Law;

2) conducting public discussion in accordance with Articles 7, 8 and 14 of the Law; 
3) analysis by the authorized body in accordance with Section 9 of the Law of the information provided in the environmental impact assessment report, any additional information provided by the business entity, as well as information received from the public during public discussion, during the implementation of the cross-border assessment procedure exposure, other information;

4) the provision by the authorized body of a reasoned opinion on environmental impact assessment, taking into account the results of the analysis provided for in paragraph 3 of this part;

5) taking into account the conclusion from the environmental impact assessment in the decision to carry out the planned activity in accordance with Section 11 of the Law [2].

Environmental impact assessment is carried out in compliance with the requirements of the legislation on environmental protection, taking into account the state of the environment in the place where it is planned to carry out the planned activity, environmental risks and forecasts, prospects for the socio-economic development of the region, capacity and types of cumulative impact (direct and indirect) on the environment, including taking into account the impact of existing facilities of the proposed activity and facilities for which decisions were made on the implementation of plans of your current activity or the question of making such decisions [2].

The planned activity, according to Article 1 of the Law, is the planned economic activity, including construction, reconstruction, technical re-equipment, expansion, re-profiling, liquidation (dismantling) of objects, and other interference with the natural environment; the planned activity does not include reconstruction, technical re-equipment, major repairs, expansion, reprofiling of facilities, other interventions in the natural environment, do not have a significant impact on the environment in accordance with the criteria approved by the Cabinet of Ministers of Ukraine [3,4].

\footnotetext{
ANALYSIS OF RECENT RESEARCHES AND PUBLICATIONS
} 
An analysis of recent studies and publications in which a solution to this problem was started showed that such scientists Adamenko Y., Adamenko O., Bazilevich V., Bystryakov I., Burkinsky B., Gavrilishin B., Galushkina T., Gerasimchuk S., Danilishin B., Daineko L., Dergacheva V., Dibrova A., Zinovchuk N., Kupalova G., Sidor V., Khvesik M., Chmyr A. and others devoted much attention to the study of various aspects of environmental impact assessment. The authors of the article, in this work, rely on research by scientists and practical experience in the implementation of the ATS procedure.

It should be noted that the environmental impact assessment in the EU started in 1985 (Council Directive 85/337 / EEC of June 27, 1985 on assessing the impact of individual public and private projects on the environment [5]), and in Ukraine - in 2018 Over a long period, the ATS procedure in the EU member states has changed and improved. This requires additional analysis, in-depth study and development in Ukraine of the relevant legislative and regulatory framework for the Association Agreement between Ukraine and the EU, which provides for the introduction of an environmental impact assessment mechanism identical to that adopted in the European Union and meeting the requirements of Directive 2011/92 / The EU of December 13, 2011 on the assessment of the impact of certain public and private projects on the environment on ATS [6].

\section{PURPOSE}

The aim of the article is to study the methodological problems of assessing the environmental impact of land use as a planned economic activity.

\section{METHODS}

Research methods, which reflect the main methods and techniques used in this scientific article, are the theoretical and methodological approach and comparative analysis of foreign experience, supplemented by a proposal for the introduction of geoinformation land-ecological-technogeochemical modeling of environmental situations, based on the use of GIS technologies for graphic overlay score cards. 


\section{RESULTS AND DISCUSSION}

Results An analysis of the environmental legislation and environmental assessment procedures of the World Bank and the leading countries of the world: the USA, Canada, Germany, Japan, Great Britain, the Netherlands, Denmark, Finland, Sweden, Iceland, Norway, Israel, and EU member states indicates many differences in the procedures environmental assessment of these countries, but it is common that the environmental assessment is carried out before the start of design and, thus, it does not depend on the investor $[1,3]$.

In general, in the process of environmental impact assessment, we propose, based on foreign experience, to highlight the following procedures:

1) preliminary environmental impact assessment - screening;

2) definition of environmental assessment tasks - scoping;

3) generalization, comparison and choice of alternatives;

4) assessment of environmental parameters;

5) mitigation;

6) decision making [1].

All stages of environmental impact assessment should be accompanied by the involvement of the public and interested parties [6,7].

In international environmental assessment systems, screening is the procedure for determining the need for an environmental assessment on a specific land use area of the relevant business entity within and outside. The screening procedure determines whether an activity is required, it is planned, an environmental assessment, and if so, what level of detail assessment should be carried out [1].

One of the features of the Law of Ukraine "On Environmental Impact Assessment" is the lack of a clearly regulated and differentiated approach to objects of varying complexity and scale of environmental impact. The selection of facilities for environmental $[1,3]$ impact assessment is carried out in accordance with the list of Article 3 "Scope of application of environmental impact assessment", which may have a significant impact on the environment and are subject to environmental impact 
assessment. This approach exists in other countries, but it is not sufficient and does not cover other types of investment activities that are beginning to develop in our country and can negatively affect the environment, and also does not take into account the typification of possible impacts, the attitude of the object to environmentally sensitive areas, the likely magnitude of the impact and stakeholder requirements for an environmental impact assessment [2].

The next stage of environmental impact assessment is scoping - it is a task definition process that identifies problems that will be important for environmental impact assessment and removes those that are not important. That is, this stage directs the research to a certain range of problems, allows you to set the goals and objectives of the research needed by experts [1] on environmental impact assessment and stakeholders, the time frame and budget of the work, in turn, prevents the time and money spent on unnecessary research. Accordingly, for Ukraine it is necessary to introduce a scoping procedure, which consists of successive interconnected steps.

The procedure for generating alternatives consists in the initial formation of the entire set of alternatives, based on the experience of interested parties in assessing the environmental impact, as well as on the latest technical and technological solutions that can lead to the achievement of the goal of the planned activity. Once the factors limiting the decision on the possibility of introducing one or another alternative are identified, the next step is to work with the generalization of certain alternatives or possible courses of action to solve the problem. Many alternative solutions, of course, are known from previous experience, are standard and easily fit into the criteria boundaries of the best solution. The generalization of alternatives, as a rule, can take place [1] in three stages: the formation, evaluation and selection of alternatives.

Based on the results of the forecast and comparison of environmental impacts, the choice is made of the alternative that was most appropriate from the point of view of environmental protection. At the same time, other alternatives are considered without fail, with the aim of further decision making on the implementation [1] of the planned activity. 
The analysis of environmental impact assessment procedures showed another difference between domestic and western environmental assessments, based on the constant participation of the public at all its stages with the goal of openness and transparency of this process. Thus, according to Article 4, "Publicity of Environmental Impact Assessment", in the process of environmental impact assessment, announcements are only provided about the beginning of public discussion of the environmental impact assessment report, information about the conclusion on environmental impact assessment and the decision to carry out planned activities [2].

The result of this step is to improve the decision-making process, acceptability for interested parties. The stage of attracting the public requires a significant investment of time and effort, but without this, projects are rarely developed on a reliable basis, it remains likely that they cause protests from the interested population. Meanwhile, public participation in the process of environmental impact assessment in Ukraine is especially important because, unlike the laws of the United States or the $\mathrm{EU}$, in our country the environmental impact assessment is not prepared by a state environmental authority independent of the investor [2], but according to article 2 laws: business entities, state authorities, local governments, which are the customers of the proposed activity [2].

The presence of these differences, however, is not a legal obstacle to the application of "Western" environmental assessment procedures, subject to the voluntary consent of the investor and the developer of the assessment and independent donor funding for public participation in the environmental impact assessment process.

The level of danger of land use of an object of economic activity for the environment and human health can be different - from insignificant to critical and even catastrophic. Moreover, the level itself is rather uncertain and, as a rule, corresponds to the initial ecological state [1] of the environment, which was before the planned activity. Therefore, it is very important to create an environmental safety system that allows you to manage forecast impacts, monitor changes in the 
environmental situation, implement measures to minimize impact and evaluate them. At the same time, environmental management practices should bring [1] the land use of the enterprise to a new environmentally friendly round of development of the industry. In the system of environmental safety of the planned activity, developed by us, scientifically substantiated several interconnected blocks (Figure 1).

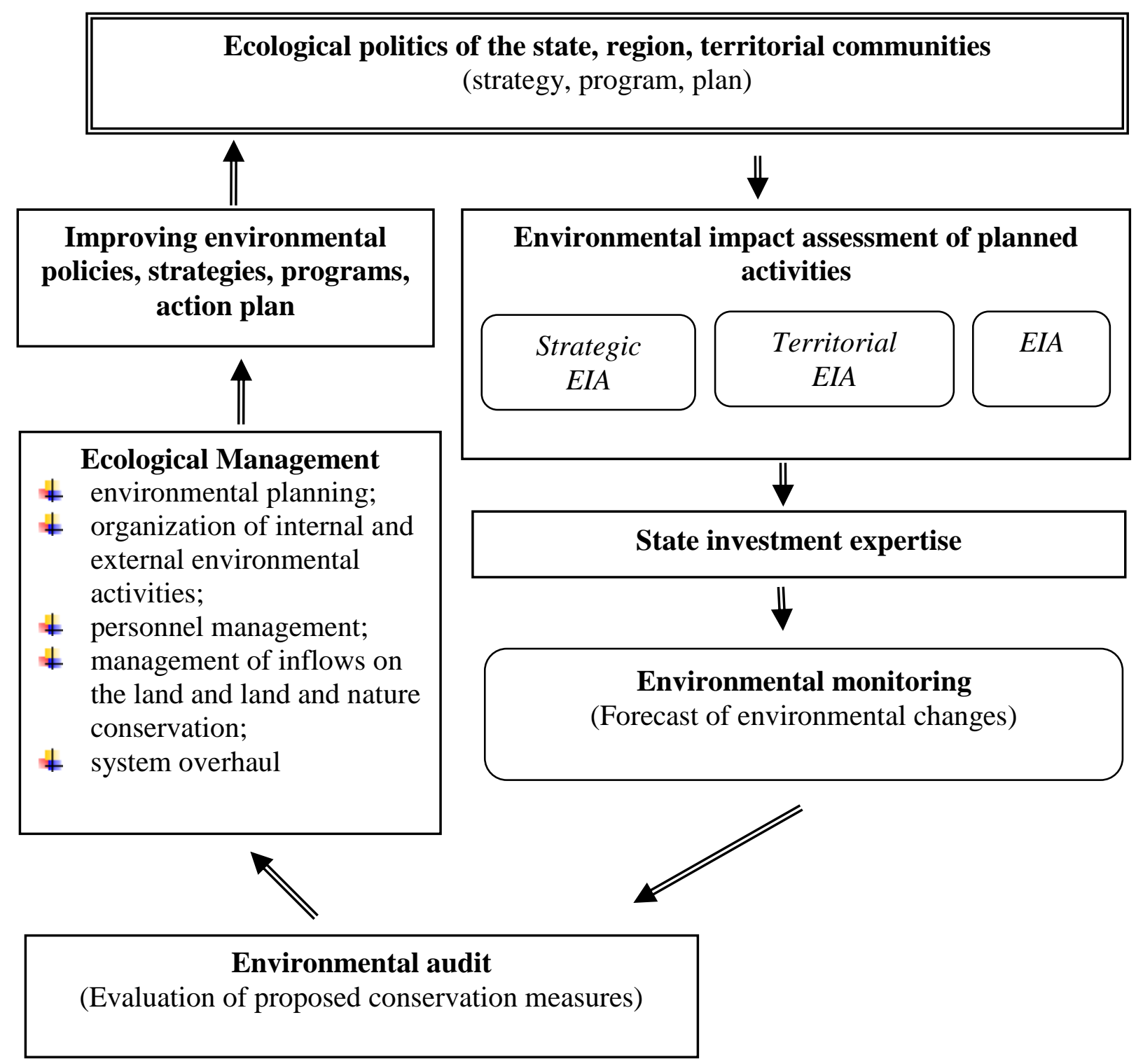

Figure 1. Logical-zmistovna scheme of interdependence of internal affairs bodies in environmental safety systems in Ukraine 
Performing a comparative analysis of the possible methodologies of environmental service committees, we propose the following methodology for geoinformation of land-ecological and technological modeling of the environmental situation, which is used when using GIS technologies for graphical, card assessment, both at the beginning of the stages and in production., The results of the developed picture are disclosed in the environment program, when the GIS is used according to the template, and then automatically layered layers, placing one above the other [1].

As a result of system analysis, a complex model of mapping in the GIS environment is obtained, in which work on abiotic, biotic, social and technogenic factors is noted. At our disposal, this card is a simple opportunity to produce an alternative with verified documents for long-term training. A model is proposed that includes all the components that manage to do this and create their strength under the influence of natural and technogenic factors $[1,3]$.

Distinctive environmental safety systems are applied to environmental management, which directs the environmentally friendly activities of the enterprise and the implementation of environmental-based environmental solutions, taking into account the fact that they exist and are negative. Environmental management is based on the ISO 14000 standard [1,3].

Environmental safety is paid for activities carried out taking into account general forecasts, assessed in two ways:

Is Comparison of the projected commission (OP) with the background (OF) is required to establish [1] phased activities at the land use station;

Qi is the projected price (OP) used for environmental environmental indicators, necessary for environmental engineering activities, which should be made land use for the planned activities, as well as mandatory for economic activities.

In accordance with the harmonious combination of the system, the Commission on Long-term and Environmental Management proposes to develop a developed "Environmental Management Plan" (or "Planuta"), which should take into account what is present, in case of long-standing problems, especially important problems, and environmental problems as well as environmental aspects. environmental audit of 
decisions made. This is planned [1] to be developed in the course of many years of company research.

\section{CONCLUSIONS}

In the course of long-term environmental activities, it is proposed to present the following actions in relation to highly effective results: 1) previous environmental value related to screening; 2) the task of environmental activities - shopping; 3) generalization, comparison and choice of alternative; 4) the authenticity of the world; 5) room Reduced exposure; 6) decision making. All stages [1] of the work of the Committee should in the long term support the participation of the public and representatives of the pages.

Using the environmental safety of the proposed activity, a methodology of scientifically based actions with blocked blocks is proposed: there is an environmental policy, there is an active territorial public (strategy, program, plan); the importance of action on long-planned activities; reliable state offer; environmental monitoring; environmental audit; environmental management; improvement of environmental policy, strategy, program, planning.

\section{REFERENCES}

1. Adamenko Ya.O. Oczi`nka vplivi`v tekhnogenno nebezpechnikh ob'yekti`vna navkolishnye seredovishhe: naukovo-teoretichni` osnovi, praktichna reali`zaczi`ya: avtoref. dis. ... d- ra tekh. nauk: 21.06.01 / Nacz. tekhn. uni ver. Nafti i` gazu. I'vanoFranki`vs`k, 2006. Available at: https://tourlib.net/aref_tourism/adamenko.htm

2. Zakon Ukrainy Pro otsinku vplyvu na dovkillia. Verkhovna Rada of Ukraine. Available at: https://zakon.rada.gov.ua/laws/show/2059-19

3. Abramov I.B., Adamenko Ya.O., Levchii V.H. [ta in.] (2002). Posibnyk do rozroblennia materialiv otsinky vplyviv na navkolyshnie seredovyshche (do DBN A.2.2-1-2003) [A guide to the development of environmental impact assessment materials]. Kharkiv, Ukraine: Kharkiv State Branch of Integrated Research and 
Environmental Impact Assessment of the UkrNIINTV Institute of the State Building of Ukraine, Part 1,156; Part 2, 220.

4. Postanova Kabinetu Ministriv Ukrainy vid 13 hrudnia 2017 r. № 1010 Pro zatverdzhennia kryteriiv vyznachennia planovanoi diialnosti, yaka ne pidliahaie otsintsi vplyvu na dovkillia, ta kryteriiv vyznachennia rozshyren i zmin diialnosti ta ob'iektiv, yaki ne pidliahaiut otsintsi vplyvu na dovkillia. Verkhovna Rada of Ukraine. Available at: https://zakon.rada.gov.ua/laws/show/1010-2017-p

5. Direktiva Radi 85/337/YeES vi`d 27 chervnya 1985 r. Pro oczi`nku nasli`dki`v vplivu deyakikh gromads`kikh i` privatnikh proekti`v na navkolishnye seredovishhe. Available at: https:// menr.gov.ua/news/31278.html

6. DYREKTYVA 2001/42/IeS YeVROPEISKOHO PARLAMENTU TA RADY vid 27 chervnia 2001 r. Pro otsinku vplyvu na stan dovkillia okremykh proektiv ta prohram [On the environmental impact assessment of individual projects and programs] (2001). Official Journal of the European Communities. Ukraine : L 197, 30.

7. DYREKTYVA 2011/92/IeS YeVROPEISKOHO PARLAMENTU TA RADY vid 13 hrudnia 2011 r. Pro otsinku naslidkiv pevnykh derzhavnykh ta pryvatnykh proektiv dlia navkolyshnoho pryrodnoho seredovyshcha [On the assessment of the effects of certain public and private projects on the environment] (2001). Official Journal of the European Communities. Ukraine : 2011L0092 — UA $-15.05 .2014-001.001,32$.

\section{А.М. Третяк, И.А. Климова}

МЕТОДОЛОГИЧЕСКИЕ ПРОБЛЕМЫ ОЦЕНКИ ВЛИЯНИЯ НА ОКРУЖАЮЩУЮ СРЕДУ ЗЕМЛЕПОЛЬЗОВАНИЯ КАК

\section{ПЛАНИРУЕМОЙ ХОЗЯЙСТВЕННОЙ ДЕЯТЕЛЬНОСТИ}

Аннотация. Проведение оценки воздействия на окружающую среду землепользования как планируемой хозяйственной деятельности, связано с рядом вопросов, в частности, теоретико-методологического характера. Одна из основных проблем выработки такой теории - построение ее основания, 
отправным началом для разработки которой является определение методологической процедуры.

Несмотря на большое количество работ, посвященных исследованию различных аспектов оценки воздействия на окружающую среду, необходимо констатировать, что в экологической литературе так и не сформировано устойчивой, полноценной дефиниции этого понятия.

Цель статьи - обзор и составление сформированных по определенным критериям в доктрине экологического законодательства направлений и подходов к определению понятия оценки воздействия на окружающую среду землепользования как планируемой хозяйственной деятельности, освещение их разнородного и общего характера для выработки целостного представления о способах понимания этого понятия и их классификацию, а также изложено собственное видение оптимальной методологической основы для определения понятия оценки воздействия на окружающую среду землепользования.

На примере зарубежного опыта установлено, что в современный период широко признанным являются следующие процедуры: предыдущая экологическая оценка воздействий - скрининг; определение задач экологической оценки - скоупинг; генерализация, сравнение и выбор альтернатив.

C позиции авторов, предлагается дополнить оценку влияния на окружающую среду также следующими этапами: оценка параметров окружающей среды; смягчение воздействий; принятие решения.

На основании анализа рассмотреной методологий оценки экологической ситуации, нами предлагается методология геоинформационного земельноэколого-техногеохимического моделирования экологических ситуаций, основанная на применении ГИС-технологий для графического наложения оценочных карт.

Данная методология является оптимальной основой для определения оценки воздействия на окружающую среду землепользования как планируемой 
хозяйственной деятельности, как на ранних стадиях оценки воздействия на окружающую среду, так и при сравнении альтернатив.

Ключевые слова: понятие оценки воздействия на окружающую среду землепользования как планируемой хозяйственной деятельности; процедуры оценки; плановая хозяйственная деятельность, «скрининг»; «скоупинг»; «генерализация»; «методология геоинформационного земельно-экологотехногеохимического моделирование»; ГИС-технологии. 